\title{
Distribution and sources of $n$-alkanes in surface sediments of Taihu Lake, China
}

\author{
Yunlong $\mathrm{Yu}^{1}$, Yuanyuan $\mathrm{Li}^{2}$, Zhigang Guo², Hua Zou* \\ 1 Jiangnan University, China \\ School of Environmental and Civil Engineering \\ ${ }^{2}$ Fudan University, China \\ Department of Environmental Science and Engineering \\ *Corresponding author's e-mail: zouhua@jiangnan.edu.cn
}

Keywords: $n$-alkanes, surface sediments, Taihu Lake.

\begin{abstract}
The last study on $n$-alkanes in surface sediments of Taihu Lake was in 2000, only 13 surface sediment samples were analysed, in order to have a comprehensive and up-to-date understanding of $n$-alkanes in the surface sediments of Taihu Lake, 41 surface sediment samples were analyzed by GC-MS. $\mathrm{C}_{10}$ to $\mathrm{C}_{37}$ were detected, the total concentrations of $n$-alkanes ranged from $2109 \mathrm{ng} \mathrm{g}^{-1}$ to $9096 \mathrm{ng} \mathrm{g}^{-1}$ (dry weight). There was strong odd carbon predominance in long chain n-alkanes and even carbon predominance in short chain $n$-alkanes. When this finding was combined with the analysis results of wax n-alkanes (WaxCn), carbon preference index (CPI), unresolved complex mixture (UCM), hopanes and steranes, it was considered that the long chain $n$-alkanes were mainly from terrigenous higher plants, and that the short chain $n$-alkanes mainly originated from bacteria and algae in the lake, compared with previous studies, there were no obvious anthropogenic petrogenic inputs. Terrestrial and aquatic hydrocarbons ratio (TAR) and $\mathrm{C}_{21}{ }^{-} \mathrm{C}_{25}{ }^{+}$indicated that terrigenous input was higher than aquatic sources and the nearshore $n$-alkanes were mainly from land-derived sources. Moreover, the distribution of short chain $n$-alkanes presented a relatively uniform pattern, while the long chain $n$-alkanes presented a trend that concentrations dropped from nearshore places to the middle of lake.
\end{abstract}

\section{Introduction}

$n$-Alkanes are important constituents of organic matter and are widely distributed in the environment (Asia et al. 2009, Rosik-Dulewska et al. 2012). They have received increasing scientific attention as molecular markers to trace the origin of organic matter (Tsapakis et al. 2010; Macías-Zamora, 1996). However, the sources of $n$-alkanes are considerably complex, except for anthropogenic sources, such as petroleum pollution, there are several natural sources of $n$-alkanes, such as terrestrial plant waxes, phytoplankton, bacteria, and diagenetic transformation of biogenic precursors (Maioli et al. 2010). Consequently, the source apportionment of $n$-alkanes has become a core research subject in related studies.

Taihu Lake is the second largest freshwater lake in China and the largest lake in the east of China, located in the Yangtze River delta, the economic center of China, in addition, it is one of the most densely populated areas in China (Zhou et al. 2012), and consequently, the significance of its ecological environment is self-evident.

The majority of the studies conducted on Taihu Lake sediments have focused on persistent organic pollutants, such as PAHs, organochlorine pesticides, and polychlorinated biphenyls (Zhao et al. 2009, Wang et al. 2003). Research on $n$-alkanes has been ignored, and studies on $n$-alkanes are few in number, the last study on $n$-alkanes was in 2000, only 13 surface sediment samples were analysed (Qu et al. 2007), consequently, through the analysis of 41 surface sediment samples from Taihu Lake, this study adopted a systematic approach to determine the distributions and sources of $n$-alkanes, it is hoped that this research will provide a comprehensive and up-to-date understanding of $n$-alkanes in the surface sediments of Taihu Lake and will help to provide background information for ecological and environmental research of the lake.

\section{Material and methods}

\section{Sampling}

Taihu Lake is a shallow lake with an average depth of about $2 \mathrm{~m}$, maximum depth $3.34 \mathrm{~m}$, located in the east of China, between $30^{\circ} 55^{\prime} 40^{\prime \prime} \mathrm{N}$ to $31^{\circ} 32^{\prime} 58^{\prime \prime} \mathrm{N}$ and $119^{\circ} 52^{\prime} 32^{\prime \prime} \mathrm{E}$ to $120^{\circ} 36^{\prime} 10^{\prime \prime}$ E. The length of the lake is about $68.5 \mathrm{~km}$ from north to south, averaging $34 \mathrm{~km}$ from west to east with the largest width at about $56 \mathrm{~km}$, and its area is approximately $2427.8 \mathrm{~km}^{2}$.

In general, Taihu Lake probably was an ancient lagoon, as suggested by its location in the Changjiang delta where solid particles have been transported and deposited in the transitional estuarine zone. Evidence of marine sediment materials found in drill cores supported this assumption (Qin 
et al. 2007). Because the lake is located at Yangtze River delta, the activities of human, such as pesticide, chemical fertilizer, the petroleum pollution from the oil leak of ship transportation or the effluent of the factories around the lake, have important influence on Taihu Lake, however, because of more and more rigorous environmental protection policies, the pollution of agriculture, transportation and industry has decreased in recent years. The total fishery yield in the lake has increased rapidly in recent years, and the percentage of small fishes, such as Coilia ectenes taihuensis, has increased in fish catches; however, the percentage of other large fishes, such as Culter alburnus, has decreased rapidly (Mao et al. 2011).

Forty-one surface sediment samples were collected using a grab sampler in May, 2011, and the locations of sampling sites are shown in Fig. 1. They are distributed homogeneously in the lake, the depth of the sampling sites was about $2 \mathrm{~m}$. Top $3 \mathrm{~cm}$ layer was carefully removed with a stainless steel spoon for subsequent analysis. All sediment samples were wrapped in aluminum foil and stored at $-20^{\circ} \mathrm{C}$ up to the time of analysis.

\section{Analysis of $n-A l k a n e s$}

The procedures for the extraction and fractionation of $n$-alkanes followed those described by $\mathrm{Hu}$ ( $\mathrm{Hu}$ et al. 2009). To describe briefly, homogenized samples were freeze-dried and ground, and about $10 \mathrm{~g}$ of the sample was extracted by dichloromethane in a $250 \mathrm{~cm}^{3}$ Soxhlet extractor for $48 \mathrm{hr}$. Activated copper was added to remove the sulfur before extraction, after which the extracts were concentrated by rotary evaporation, solvent-exchanged to hexane and submitted to a silica-alumina (2:1) column for clean-up and fractionation. The fraction was eluted with hexane/dichloromethane $1: 1, \mathrm{v} / \mathrm{v}$. Then, the fractions were concentrated to $0.4 \mathrm{~cm}^{3}$ under a gentle $\mathrm{N}_{2}$ stream. Hexamethylbenzene was added to the extract as an internal standard prior to instrumental analysis.

n-Alkane concentrations were determined using an Agilent 5975C mass spectrometer interfaced to an Agilent 7890 gas chromatograph, and chromatographic separation was achieved by a DB-5MS capillary column $(30 \mathrm{~m}$ long $\times 0.25 \mathrm{~mm}$ inside diameter $\times 0.25 \mu \mathrm{m}$ film thickness, Agilent) with a splitless injector and a mass spectrometer detector. Helium was used as the carrier gas $\left(1.0 \mathrm{~cm}^{3} \mathrm{~min}^{-1}\right)$. Samples were injected in the splitless mode with an injector temperature of $280^{\circ} \mathrm{C}$. The oven temperature was programmed from $60^{\circ} \mathrm{C}$ to $180^{\circ} \mathrm{C}(1 \mathrm{~min}$ hold) at $8^{\circ} \mathrm{C} \mathrm{min}^{-1}$, and from $180^{\circ} \mathrm{C}$ to $300^{\circ} \mathrm{C}$ ( 2 min hold) at a $3^{\circ} \mathrm{C} \mathrm{min}^{-1}$ rate. The mass spectrum was operated in the electron ionization (EI) mode $(70 \mathrm{eV})$, and the mass scanning ranged between $\mathrm{m} / \mathrm{z} 50$ and $500 \mathrm{amu}$.

The authentic standards of $n$-alkanes $\left(\mathrm{C}_{10-40}\right)$ were used to determine the concentrations of n-alkanes. Individual $n$-alkanes were identified based on mass spectra of target compounds against the authentic standards and the retention times. The concentrations of individual $n$-alkanes were quantified relative to internal standards (five-point calibration).

Spiked blanks (standards spiked into solvent), duplicate samples and method blanks (solvent) were also conducted. In addition, surrogate standards were added to samples prior to extraction; the average surrogate recoveries were $92.2 \% \pm 14.1 \%$ for phenanthrene-d $10,75.3 \% \pm 11.9 \%$ for chrysene-d 12 , and $74.7 \% \pm 9.5 \%$ for perylene-d 12 , the paired duplicate samples agreed to within $15 \%$ of the measured values $(n=8)$. Glassware was cleaned by heating at $450^{\circ} \mathrm{C}$ for $6 \mathrm{~h}$ and solvents were distilled twice, chemicals (e.g. alumina or silica) were solvent extracted. Blank procedures showed no noticeable interference in the analysis.

\section{Methods of Source Apportionment}

The source apportionment for $n$-alkanes was done through the analysis of the carbon number distribution, $\mathrm{C}_{\max }$, and odd-even features of different chain length $n$-alkanes. The different source denotative meanings of $n$-alkanes are listed in Table 1 (Silliman et al. 2003, Goñi et al. 1997, Mead et al. 2005).

The odd-even feature was evaluated by means of some parameters, and CPI was the representative parameter. The CPI could be used to represent the odd-even predominance of the carbon number or the maturity of organic matter. The calculation formulas are shown as follows, $\mathrm{CPI}_{1}$ and $\mathrm{CPI}_{2}$ were

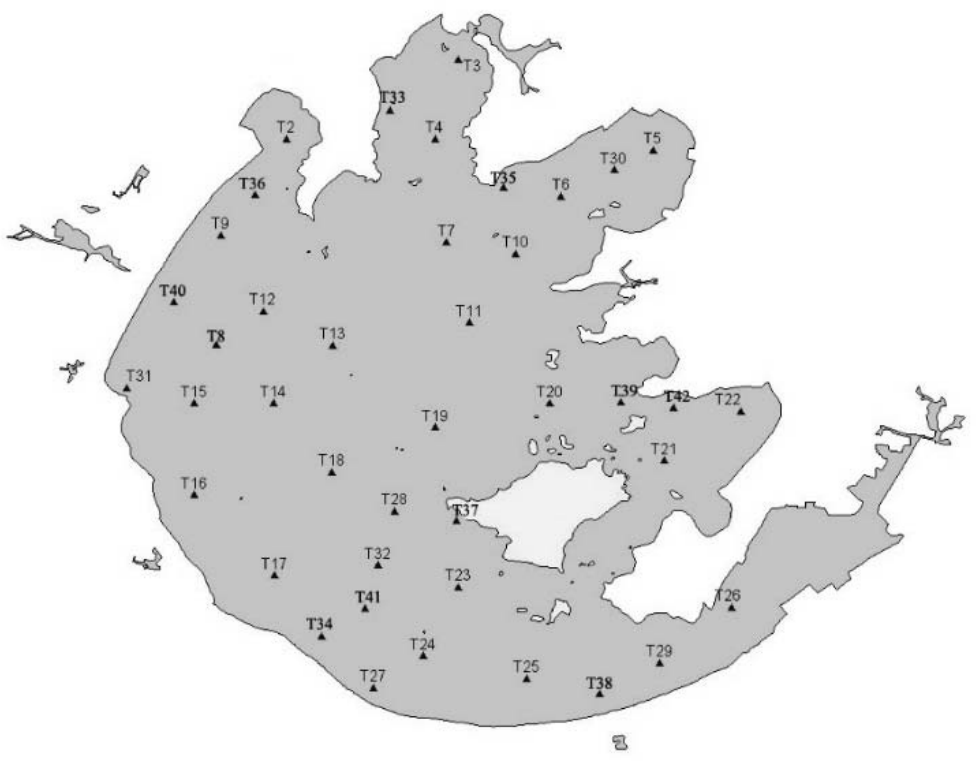

Fig. 1. Locations of sampling sites 
Table 1. Source denotative meanings of $n$-alkanes

\begin{tabular}{|c|c|c|c|}
\hline n-Alkanes & $\mathrm{C}_{\max }$ & Odd-even feature & Denotative meanings \\
\hline \multirow{2}{*}{$\begin{array}{l}\text { Short chain } \\
\quad\left(<C_{21}\right)\end{array}$} & \multirow{2}{*}{$C_{15}, C_{17}, C_{19}$} & Odd predominance & Floating or benthic algae \\
\hline & & No odd predominance & Bacterium or petroleum pollution \\
\hline \multirow{2}{*}{$\begin{array}{l}\text { Long chain } \\
\qquad\left(>C_{25}\right)\end{array}$} & \multirow{2}{*}{$\mathrm{C}_{29}, \mathrm{C}_{27}}$, & Odd predominance & Terrestrial higher plant \\
\hline & & No odd predominance & Bacterium or floating algae \\
\hline Medium chain $\left(\mathrm{C}_{23}-\mathrm{C}_{25}\right)$ & $\mathrm{C}_{23}, \mathrm{C}_{25}$ & Odd predominance & Aquatic macrophyte of fresh water or ocean \\
\hline
\end{tabular}

the CPI calculated for short chain $n$-alkanes and long chain $n$-alkanes, respectively.

$$
\begin{aligned}
& C P I_{1}=\frac{1}{2}\left(\frac{\sum_{\text {odd }} C_{15-21}}{\sum \text { even }_{14-20}}+\frac{\sum_{14 d C_{15-21}}}{\sum \text { even }_{16-22}}\right) \\
& C P I_{2}=\frac{1}{2}\left(\frac{\sum_{\text {odd }} C_{25-35}}{\sum \text { even }_{24-34}}+\frac{\sum \text { odd }_{25-35}}{\sum \text { evenC }_{26-36}}\right)
\end{aligned}
$$

In addition to the CPI, wax $n$-alkanes $\left(\mathrm{WaxC}_{\mathrm{n}}\right.$ ) are another common parameter in source apportionment of $n$-alkanes. The source denotative meaning of $\operatorname{WaxC}_{\mathrm{n}}$ is explained using $\operatorname{WaxC}_{\mathrm{n}}$ graphs. $\mathrm{WaxC}_{\mathrm{n}}$ curves present zigzag patterns, indicating that $n$-alkanes mainly originate from biological sources. $\mathrm{WaxC}_{n}$ curves are straight, indicating that they mainly originate from anthropogenic sources (Kavouras et al. 2002). The calculation formula is shown as follows:

$$
\operatorname{Wax} C_{n}=\frac{\sum\left[C_{n}-\frac{1}{2}\left(C_{n-1}+C_{n+1}\right)\right]}{\sum C_{11-37}} \times 100 \%
$$

where if $\operatorname{WaxC}_{\mathrm{n}}$ is below $0, \operatorname{WaxC}_{\mathrm{n}}$ is defined as 0 .

Furthermore, the terrestrial and aquatic hydrocarbons ratio (TAR) helps to determine whether the main source of hydrocarbons is allochthonous or autochthonous. The calculation formula is shown as follows:

$$
T A R=\frac{C_{27}+C_{29}+C_{31}}{C_{15}+C_{17}+C_{19}}
$$

\section{Results and discussion}

\section{Source apportionment of $n$-alkanes}

The analysis results for $n$-alkanes are provided in Table 2 . The data in the table indicate that there was strong odd-even carbon predominance in long chain $(\geq \mathrm{C} 25) n$-alkanes in all samples with $\mathrm{C}_{\max }$ at $\mathrm{C}_{29}$ or $\mathrm{C}_{31}$. The average $\mathrm{CPI}_{2}$ was 2.28 , suggesting the presence of prominent terrestrial inputs (Aboul-Kassim et al. 1996).

Interestingly, 31 samples were found for which the $\mathrm{C}_{\max }$ in short chain $n$-alkanes was $\mathrm{C}_{16}$, an even carbon number, whereas only 10 samples had a $\mathrm{C}_{\max }$ that was an odd carbon number, $\mathrm{C}_{17}$ or $\mathrm{C}_{13}$. In addition, the average $\mathrm{CPI}_{1}$ was 0.57 , which is a sign that shows even carbon number predominance in short chain $n$-alkanes. It has been reported that the even carbon number predominance of short chain $n$-alkanes in sediments was mainly from bacteria, fungi, and yeast species, and from possible petroleum-derived inputs ( $\mathrm{Hu}$ et al. 2009, Harji et al. 2008). The unresolved complex mixture (UCM) is useful for source determination, which was not resolved during the gas chromatography analysis and appears as a hump in the chromatogram (Lima et al. 2012). UCM is normally associated with petroleum hydrocarbon distributions. However, when eluting in short chain $n$-alkanes, UCM might be considered to be formed by bacterial degradation of natural organic inputs such as algal detritus (Oliveira et al. 2011). In this study, humps were detected in short chain $n$-alkanes of most samples with different content; a sample chromatogram is shown in Fig. 2. It suggests that the short chain $n$-alkanes might have mainly originated from bacterial degradation. Hopanes and steranes have been used for source identification and can be used to fingerprint spilled oil (Zaghden et al. 2007). Hopanes and steranes have also been analyzed in this study, but no significant amounts of hopanes or steranes were found in any of the analyzed sediments. The lack of these compounds might also suggest non-petroleum inputs to the sediments. Therefore, the short chain $n$-alkanes in the sediments of Taihu Lake are concluded to have mainly originated from bacteria, algae, or other microorganisms in the lake.

Moreover, according to the $\mathrm{WaxC}_{\mathrm{n}}$ graphs shown in Fig. 3 , for both short chain $n$-alkanes and long chain $n$-alkanes, the $\mathrm{WaxC}_{\mathrm{n}}$ curves showed zigzag variations. This shows that the $n$-alkanes mainly originated from biological sources, which confirms the above conclusion.

In conclusion, the short chain $n$-alkanes in the surface sediments of Taihu Lake mainly originated from bacteria and algae in the lake, and the long chain $n$-alkanes in the surface sediments of Taihu Lake mainly originated from terrigenous higher plants. This result is different with the previous study of Qu et al.; they believed that anthropogenic petrogenic input was one of the main sources of $n$-alkanes in the surface sediments of Taihu Lake (Qu et al. 2007). Such difference reflects that the petroleum pollution was cut down in the past 10 years, this may attribute to the more and more rigorous environmental protection policies that have been taken into action in the Taihu Lake area.

As shown by the data in Table 2 , high TAR values $(>7)$ were observed in the coastal areas with the maximum $(\approx 16)$ at T40, indicating that the nearshore $n$-alkanes were mainly from land-derived sources. In addition, the average TAR was 3, also suggesting that terrigenous sources were the main contributors of the $n$-alkanes. Except for TAR, the concentrations of $\mathrm{C}_{21}$. 
Table 2. Analysis results of $n$-alkanes

\begin{tabular}{|c|c|c|c|c|c|c|}
\hline Site & Concentration $\left(\mathrm{ng} \mathrm{g}^{-1}\right)$ & $\mathrm{C}_{\max }$ & $\mathrm{CPI}_{1}$ & $\mathrm{CPI}_{2}$ & $\mathrm{C}_{21}-1 \mathrm{C}_{25}{ }^{+}$ & TAR \\
\hline T2 & 5454 & $\mathrm{C}_{29}, \mathrm{C}_{16}$ & 0.74 & 3.08 & 1.36 & 2.28 \\
\hline T3 & 4453 & $\mathrm{C}_{29}, \mathrm{C}_{16}$ & 0.60 & 2.77 & 1.20 & 2.25 \\
\hline $\mathrm{T} 4$ & 4372 & $\mathrm{C}_{17}, \mathrm{C}_{29}$ & 0.75 & 2.47 & 0.81 & 1.28 \\
\hline T5 & 6002 & $\mathrm{C}_{17}, \mathrm{C}_{29}$ & 0.94 & 3.12 & 1.10 & 1.53 \\
\hline T6 & 4695 & $\mathrm{C}_{17}, \mathrm{C}_{29}$ & 0.96 & 2.25 & 0.56 & 0.72 \\
\hline $\mathrm{T7}$ & 4505 & $\mathrm{C}_{16}, \mathrm{C}_{29}$ & 0.64 & 2.50 & 0.62 & 1.04 \\
\hline T8 & 7554 & $\mathrm{C}_{16}, \mathrm{C}_{31}$ & 0.45 & 1.91 & 0.37 & 0.71 \\
\hline T9 & 8575 & $\mathrm{C}_{16}, \mathrm{C}_{29}$ & 0.37 & 2.29 & 0.46 & 0.98 \\
\hline T10 & 3347 & $\mathrm{C}_{16}, \mathrm{C}_{29}$ & 0.48 & 2.48 & 0.87 & 1.95 \\
\hline T11 & 3712 & $\mathrm{C}_{16}, \mathrm{C}_{29}$ & 0.54 & 2.57 & 0.60 & 1.23 \\
\hline T12 & 3170 & $\mathrm{C}_{16}, \mathrm{C}_{31}$ & 0.65 & 2.04 & 0.49 & 0.77 \\
\hline T13 & 2862 & $C_{16}, C_{31}$ & 0.55 & 2.45 & 0.81 & 1.48 \\
\hline T14 & 4103 & $\mathrm{C}_{16}, \mathrm{C}_{31}$ & 0.53 & 2.41 & 0.78 & 1.50 \\
\hline T15 & 3723 & $\mathrm{C}_{29}, \mathrm{C}_{16}$ & 0.43 & 2.78 & 1.04 & 3.01 \\
\hline T16 & 3958 & $\mathrm{C}_{16}, \mathrm{C}_{29}$ & 0.55 & 2.56 & 0.67 & 1.34 \\
\hline T17 & 3368 & $\mathrm{C}_{16}, \mathrm{C}_{29}$ & 0.56 & 2.53 & 0.72 & 1.48 \\
\hline T18 & 3436 & $\mathrm{C}_{16}, \mathrm{C}_{29}$ & 0.46 & 2.55 & 0.85 & 2.27 \\
\hline T19 & 2372 & $\mathrm{C}_{16}, \mathrm{C}_{29}$ & 0.55 & 2.33 & 0.76 & 1.43 \\
\hline T20 & 3399 & $\mathrm{C}_{16}, \mathrm{C}_{29}$ & 0.42 & 1.85 & 0.60 & 1.39 \\
\hline T21 & 3771 & $\mathrm{C}_{16}, \mathrm{C}_{29}$ & 0.50 & 2.10 & 0.50 & 0.98 \\
\hline T22 & 5258 & $\mathrm{C}_{16}, \mathrm{C}_{29}$ & 0.57 & 3.76 & 0.83 & 1.59 \\
\hline T23 & 3518 & $\mathrm{C}_{16}, \mathrm{C}_{29}$ & 0.48 & 1.80 & 0.49 & 0.91 \\
\hline T24 & 2771 & $\mathrm{C}_{29}, \mathrm{C}_{16}$ & 0.35 & 2.28 & 0.99 & 3.31 \\
\hline T25 & 5545 & $\mathrm{C}_{29}, \mathrm{C}_{16}$ & 0.66 & 3.51 & 1.30 & 2.55 \\
\hline T26 & 9096 & $\mathrm{C}_{31}, \mathrm{C}_{17}$ & 0.89 & 4.22 & 1.46 & 2.29 \\
\hline T27 & 3613 & $\mathrm{C}_{31}, \mathrm{C}_{16}$ & 0.45 & 2.37 & 0.93 & 2.17 \\
\hline T28 & 3512 & $\mathrm{C}_{16}, \mathrm{C}_{31}$ & 0.46 & 2.22 & 0.60 & 1.29 \\
\hline T29 & 3215 & $\mathrm{C}_{16}, \mathrm{C}_{29}$ & 0.49 & 2.43 & 0.63 & 1.26 \\
\hline T30 & 3962 & $\mathrm{C}_{16}, \mathrm{C}_{29}$ & 0.59 & 2.53 & 0.79 & 1.61 \\
\hline T31 & 3115 & $\mathrm{C}_{29}, \mathrm{C}_{16}$ & 0.56 & 2.49 & 1.31 & 2.86 \\
\hline T32 & 9059 & $\mathrm{C}_{16}, \mathrm{C}_{29}$ & 0.40 & 1.76 & 0.30 & 0.54 \\
\hline T33 & 3147 & $\mathrm{C}_{29}, \mathrm{C}_{17}$ & 0.92 & 3.01 & 2.08 & 4.27 \\
\hline T34 & 2892 & $\mathrm{C}_{31}, \mathrm{C}_{13}$ & 0.53 & 3.07 & 1.32 & 5.67 \\
\hline T35 & 2286 & $\mathrm{C}_{29}, \mathrm{C}_{16}$ & 0.55 & 2.73 & 1.41 & 3.53 \\
\hline T36 & 7394 & $\mathrm{C}_{29}, \mathrm{C}_{17}$ & 0.98 & 3.19 & 2.70 & 5.16 \\
\hline T37 & 2109 & $\mathrm{C}_{29}, \mathrm{C}_{13}$ & 0.48 & 2.79 & 1.66 & 6.03 \\
\hline T38 & 3980 & $\mathrm{C}_{29}, \mathrm{C}_{17}$ & 0.68 & 3.28 & 2.80 & 5.59 \\
\hline T39 & 2660 & $\mathrm{C}_{31}, \mathrm{C}_{13}$ & 0.41 & 3.31 & 1.55 & 7.25 \\
\hline $\mathrm{T} 40$ & 8100 & $\mathrm{C}_{29}, \mathrm{C}_{16}$ & 0.45 & 1.33 & 7.23 & 15.83 \\
\hline T41 & 3709 & $\mathrm{C}_{29}, \mathrm{C}_{16}$ & 0.34 & 1.77 & 2.99 & 9.59 \\
\hline T42 & 8646 & $\mathrm{C}_{29}, \mathrm{C}_{16}$ & 0.50 & 1.44 & 4.68 & 9.53 \\
\hline
\end{tabular}

and $\mathrm{C}_{25}{ }^{+}$could also reflect the relationship between terrestrial sources and aquatic sources. The concentration curves of total $n$-alkanes, long chain $n$-alkanes, and short chain $n$-alkanes are shown in Fig. 4. It is found that the long chain $n$-alkanes curve was more matched with the total $n$-alkanes curve, implying that terrigenous higher plants had more contribution in the $n$-alkanes input. However, it was not the same for all sites; different sites had different main contributors, for example, the main contributors of T8, T9, and T32 were bacteria and algae in the lake, although the main contributors of T26, T36, T38, $\mathrm{T} 40$, and $\mathrm{T} 42$ were terrigenous higher plants. The results were in agreement with the TAR data. 


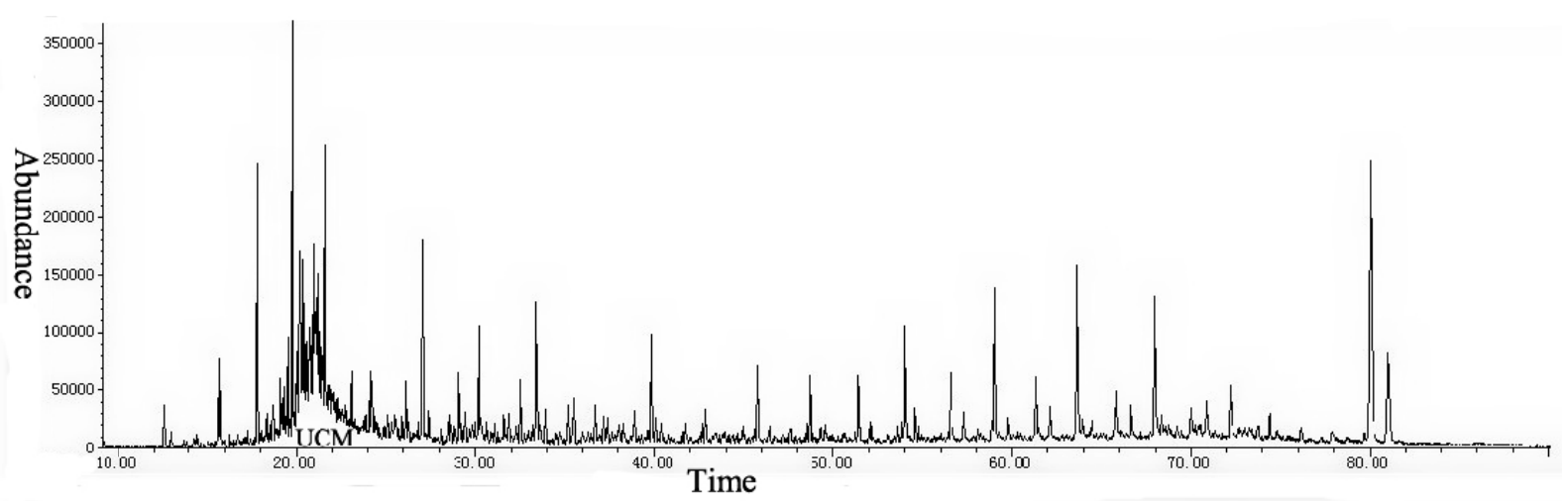

Fig. 2. Chromatogram of a sample
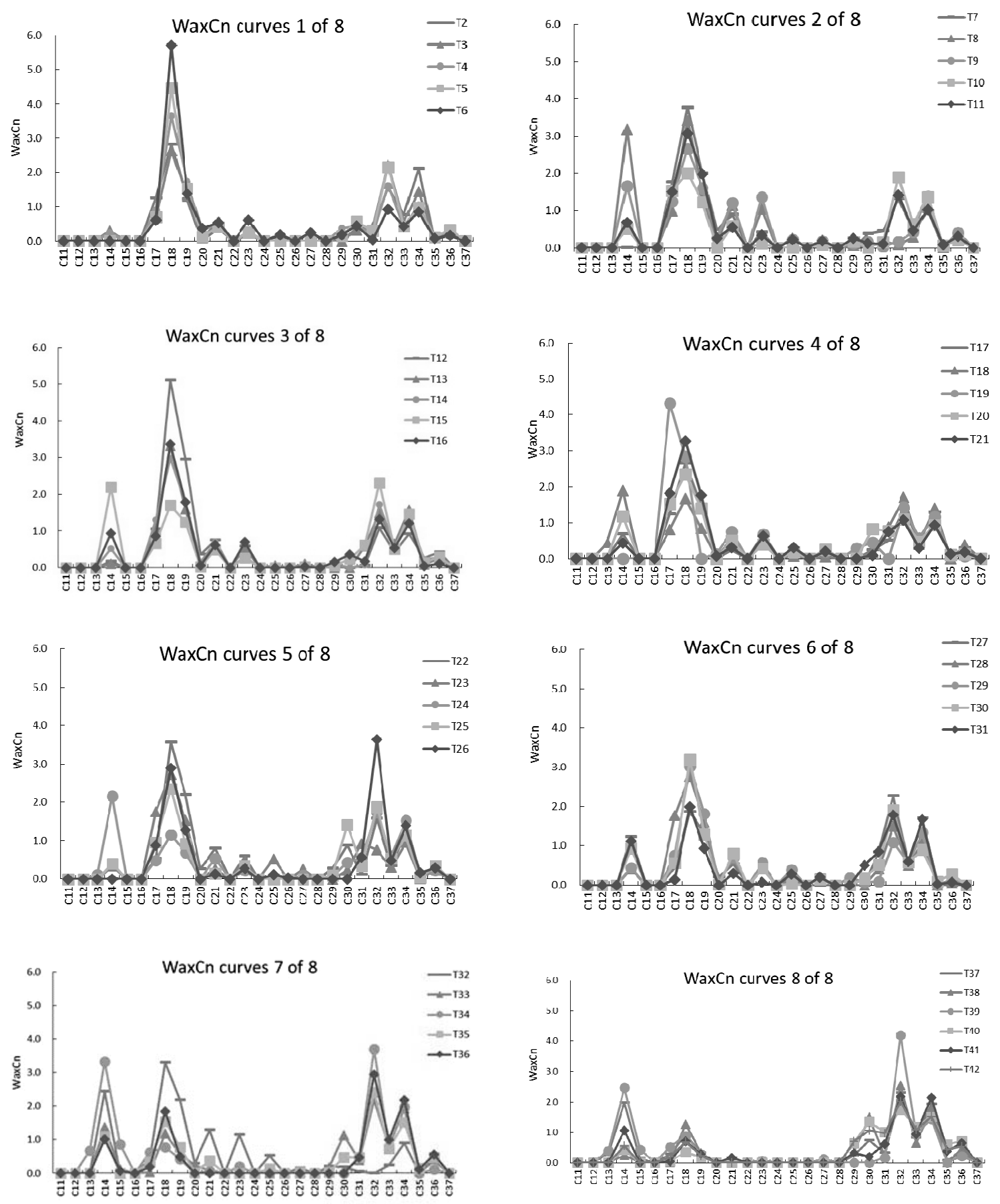

Fig. 3. WaxCn graphs from sample $T 2$ to $T 42$ 


\section{Distribution of $n$-Alkanes}

The total concentration of $n$-alkanes was between $2109 \mathrm{ng} \cdot \mathrm{g}^{-1}$ and $9096 \mathrm{ng} \cdot \mathrm{g}^{-1}$. The average was $4498 \mathrm{ng} \cdot \mathrm{g}^{-1}$, and the maximum was located at T26, and then at T32. The minimum was located at $\mathrm{T} 37$ followed by the next minimum at T35.

Because of the different sources of short chain $n$-alkanes and long chain $n$-alkanes, this study separately analyzed the distribution of $n$-alkanes from short chains and long chains. The distribution of long chain $n$-alkanes presented a trend that the concentration dropped from nearshore places to the middle of lake (as shown in Fig. 5), similar to the case of the west coast of Africa, where alkane concentrations were found to decrease as the offshore distance increased (Schefuß et al. 2004). Long chain $n$-alkanes migrated to the middle of the lake mainly through adsorption onto particulate matter or dissolved in organic matter, after which they entered the sediments by adsorption or sedimentation (Meyers 2003). The content that entered the sediments in the middle of the lake was related to the sedimentation rate and migration distance, and the sedimentation rate was also related to the terrain, hydrologic conditions, and other such factors. Terrain with a slight gradient was good for sedimentation. A shorter migration distance resulted in more long chain $n$-alkanes entering the sediments. Because of the slow sedimentation rate caused by the flat terrain of Taihu Lake, most long chain $n$-alkanes were degraded as they migrated to the middle of the lake, and the distribution of long chain $n$-alkanes overall presented a trend according to which concentration decreased as offshore distance increased. In addition, the nearshore places had more terrigenous higher plants by river scouring, and this also made the concentration of long chain $n$-alkanes at the nearshore places higher.

The distribution of short chain $n$-alkanes was relatively uniform, except for T8, T9 and T32 (shown in Fig. 6). The uniform distribution might be attributable to the floating lifestyle of bacteria and algae; the uniform distribution of short chain $n$-alkanes was the same as in Nam Co Lake, China (Lin et al. 2009). The reason that T8, T9 and T32 showed much higher short chain $n$-alkane concentrations than other sites was not clear.

\section{Conclusions}

The analysis of the composition and distribution of $n$-alkanes in the surface sediments of Taihu Lake permitted an assessment of the sources, and there was strong odd

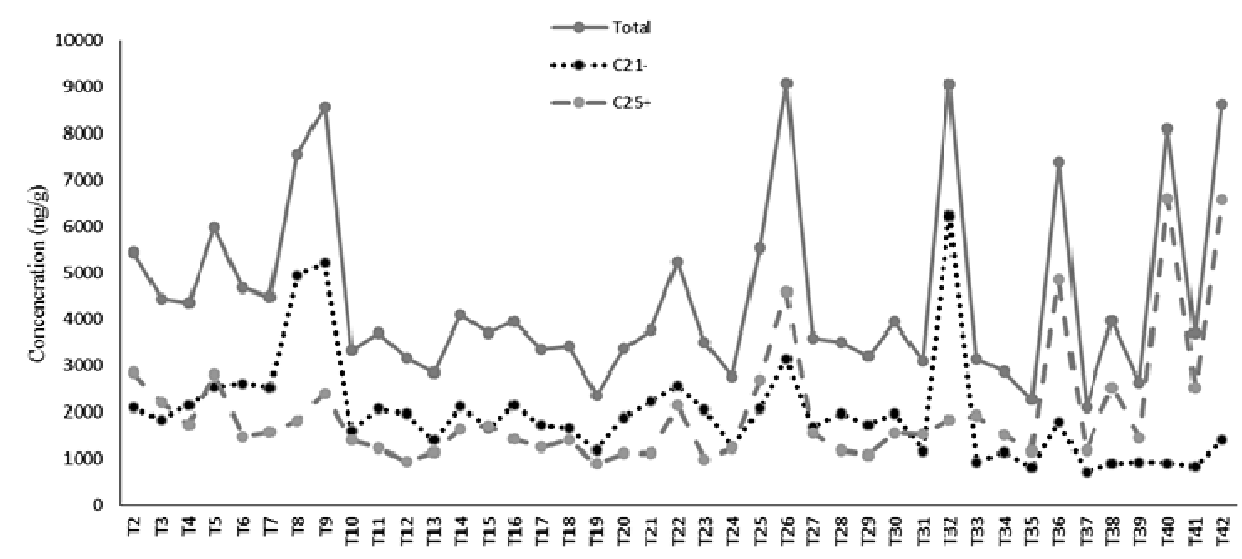

Fig. 4. Concentration curves of total n-alkanes, long chain n-alkanes and short chain n-alkanes

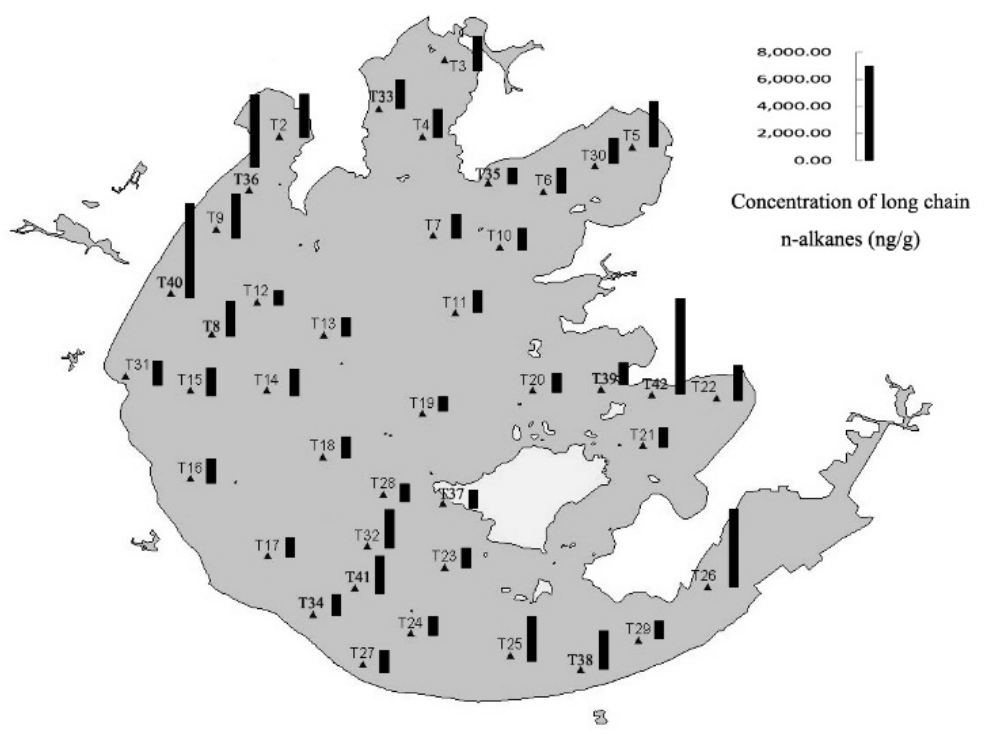

Fig. 5. Distribution map of long chain n-alkanes 


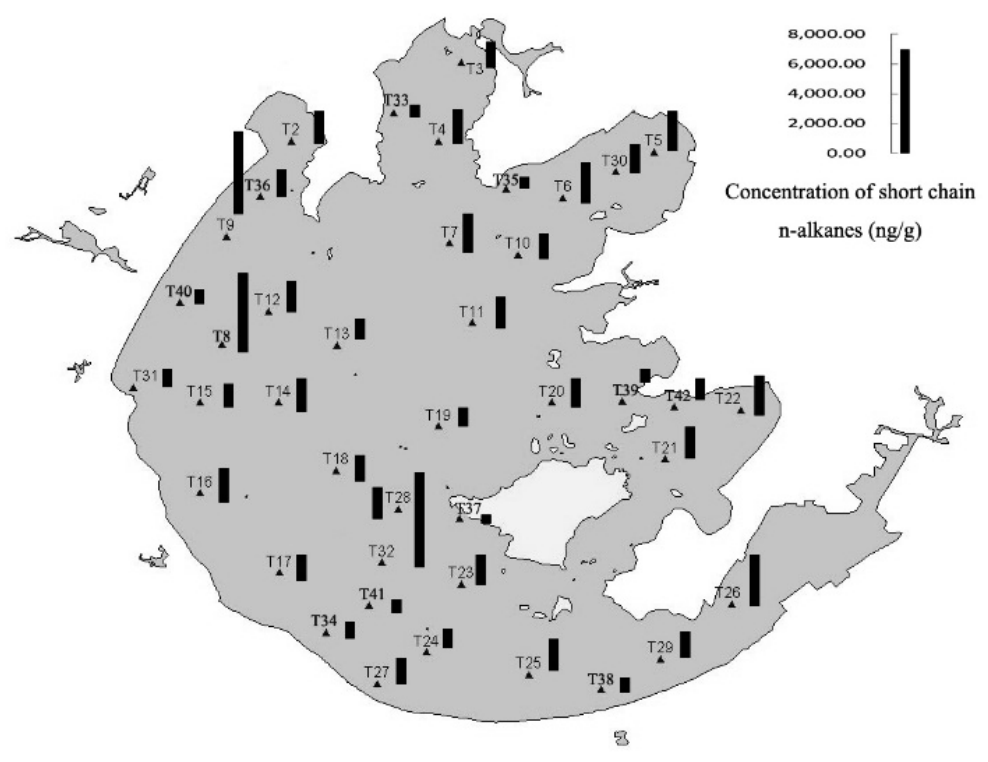

Fig. 6. Distribution map of short chain n-alkanes

carbon predominance in long chain $n$-alkanes and even carbon predominance in short chain $n$-alkanes. Combined with the analyses of CPI, $\operatorname{WaxC}_{\mathrm{n}}, \mathrm{UCM}$, hopanes and steranes, it was determined that the long chain $n$-alkanes were mainly from terrigenous higher plants and that the short chain $n$-alkanes mainly originated from bacteria and algae in the lake, compared with previous studies, there were no obvious anthropogenic petrogenic inputs. TAR and $\mathrm{C}_{21}{ }^{-} / \mathrm{C}_{25}{ }^{+}$indicated that the terrigenous input was higher than aquatic sources and the nearshore $n$-alkanes were mainly from land-derived sources. In addition, the distribution of short chain $n$-alkanes was relatively uniform, long chain $n$-alkanes showed a trend of reducing concentration from nearshore places to the middle of the lake, the results of this study could provide a comprehensive and up-to-date understanding of $n$-alkanes in the surface sediments of Taihu Lake, and to provide background information for ecological and environmental research on Taihu Lake.

\section{Acknowledgements}

This study was supported by National Special Project on Water Pollution Control and Management (Grant \# (2012ZX07503-002)). We are grateful to editors and reviews for their helpful suggestions about our study.

\section{References}

Aboul-Kassim, T.A. \& Simoneit, B.R. (1996). Lipid geochemistry of surficial sediments from the coastal environment of Egypt I. Aliphatic hydrocarbons-characterization and sources, Marine Chemistry, 54, 1, pp. 135-158.

Asia, L., Mazouz, S., Guiliano, M., Doumenq, P. \& Mille, G. (2009). Occurrence and distribution of hydrocarbons in surface sediments from Marseille Bay (France), Marine Pollution Bulletin, 58, 3, pp. 443-451.

Goñi, M.A., Ruttenberg, K.C. \& Eglinton, T.I. (1997). Sources and contribution of terrigenous organic carbon to surface sediments in the Gulf of Mexico, Nature, 389, pp. 275-278.

Harji, R.R., Yvenat, A. \& Bhosle, N.B. (2008). Sources of hydrocarbons in sediments of the Mandovi estuary and the Marmugoa harbour, west coast of India, Environment International, 34, 7, pp. 959-965.

Hu, L.M., Guo, Z.G., Feng, J.L., Yang, Z.S. \& Fang, M. (2009). Distributions and sources of bulk organic matter and aliphatic hydrocarbons in surface sediments of the Bohai Sea, China, Marine Chemistry, 113, pp. 197-211.

Kavouras, I.G. \& Stephanou, E.G. (2002). Particle size distribution of organic primary and secondary aerosol constituents in urban, background marine, and forest atmosphere, Journal of Geophysical Research, 107, D8, pp. 1-12.

Rosik-Dulewska, C., Ciesielczuk, T. \& Krysiński, M. (2012). Organic pollutants in groundwater in the former airbase, Archives of Environmental Protection, 38, 1, pp. 27-34. 